\title{
Natural Environment Character Education Based on Islam
}

\author{
Muhammad Yusuf ${ }^{1}$ Mardan $^{2}$, Nahdiyah $^{3}$ \\ ${ }^{I}$ Sekolah Tinggi Agama Islam Al-Furqan, Makassar, Indonesia \\ ${ }^{2,3}$ Universitas Islam Negeri Alauddin, Makassar, Indonesia \\ email: 1*Muhammadyusuf@uin-alauddin.co.id \\ 2mardan@uin-alauddin.ac.id, ${ }^{3}$ nahdhiyah.dhiyah@uin-alauddin.co.id
}

\begin{abstract}
Character education oriented toward the environmental care is required in the local, national and global scales following the environmental crisis and the unbalance of the ecosystem that harms mankind. Education is the most effective means for dealing the aforementioned challenges. Drawing on the concept of the Quran and Sunnahthematically, the complete concept regarding the character education oriented toward the environmental care was uncovered, namely the education of environmental awareness based transcendental values because its correspondence to the nature of mankind. The highest value of character education is based on the spirituality that views the nature as tajjalli(the self-manifestation of God) and signal of god. The principles of character education should be well-planned, gradual, controllable, evaluative and sustainable. In such a context, understanding, habituation, exemplary models, culture, consistent regulation are required, which are subsequently internalized and at the end become a character.
\end{abstract}

Keywords- Character Education, Environmental Care, Environmental Education, and Spiritual

\section{INTRODUCTION}

Character education and natural environmental care have been critical issues in recent years, headlined either in local, national or international media, in that they remain the global challenges affecting other related aspects. The improvement of people's education levels does not always correspond to their character development. In some cases, educated people perform bad deeds depicting their weakness of attitude and character [1].

On the other hand, the national education plays essential roles in improving the competences and shaping dignified characters and national civilization for the sake of educating the nation state, which may result in the development of students' potentials to be faithful and pious towards god, noble in action, healthy, knowledgeable, skillful, creative, independent, and to be democratic and responsible members of the state [2]. In this context, education and environment remain a single entity that is inseparable from each other. Education is not independent from the three educational environments, namely families, schools or universities and society. One of 
the fundamentally harmonious relations from the three natural tenets is the human relation with the nature or environment [3]. The view of the nature in terms of local wisdom and ecological awareness becoming the traditional characters of the non-written cultures remains neglected by the people moving towards more rational and mechanistic thoughts [4].Recent natural environmental disasters occurring both in the local, national and global scales are mostly caused by humans. The environmental pollution and devastation in the sea, forest, air, water, land, and etc., are basically affected by wrong deeds of irresponsible and selfish people at the expense of the environment conservation [5]..Allah firmly warns mankind that the damages occurring on Earth are a result of their own deeds.All is caused by the loss of their responsibility and credibility respectively as a caliph and trustee for solving the environmental problems. Despite needed, science and technology are not adequate to address the aforementioned issues inasmuch as we need to bring the religious value into the action to avoid the environmental crisis, $n$. name, so that enforcing the generation of awareness through a religious approach.

Atho' Mudzhar opines that there are four main reasons for the significant immergence of Islamic rules that manage the relationship between human and environment (ecological jurisprudence). First, the realistic condition of critical environment gets worse and worse both in the Muslim states and global world. This requires Islamic teachings as the religion of peace for universe, rahmatan lil 'alaminn [6].Second, Muslims need a comprehensive framework related to the perspective and ways of participating in the environmental conservation issues.Classical fiqh education is deemed no longer inadequate and has yet been accommodatin in terms of operational guidance on the environmental conservation in the perspective and insight into the modern environmental crisis. Third, the environmental Fiqh (Islamic jurisprudence) education has not been regarded as a discipline in the realm of Islamic studies. The ontological and epistemological grounds remain debatable, so it is still thought to be a part of environmental studies. Indeed, in the Fiqh of $\mathrm{Mu}^{\text {'amalah (social interaction) }}$ are themes regarding environments, such as thaharah, ihya al-mawat, hunting law, hima', and etc., yet they remain generic and ethical. Four, the environmental fiqh is seen as the mother of environmental conservation based on the Islamic principles that need to be included into the education programs in that the awareness of the environmental conservation can be very effective through the educational and cultural strategies [6].

Through education, educators have some room and opportunities to promote the importance of natural and environmental conservation. In its subsequent studies is presented how education views and implements the materials by integrating them with the environmental awareness of the students for sake of the inner character building pertinent to the natural and environmental care. From this point of view, the environmental awarness for sustainable developmentis of paramount importance for the future development can be sustained on the hand of the future generation. For this reason, the marriage between generic and religious lessons will be more effective in promoting the characters of environmental care. 


\section{METHOD}

The concepts of character education were presented through the guidelines of the Qur'an and Hadith of the Prophet Muhammad SAW. Relevant Quranic verses related to character education of environmental care were initially. First, the researcher highlighted the terms, which semantically and closely related to character education and environment, found in the Qur'an. The verses were then analyzed through using al-Mu'jam al-Mufahras li Alfazh Al-Qur'an al-Karim coined by Abd al-Baqiy [7]. Subsequently, some of them were identified and classified into their chronological delivery [8]. Third, they were presented through thematic data analysis procedures first coined by Abd. Al-Hayy al-Farmawi . Fourth, historical approach was applied to gain the comparison of the initial meaning taught by the Prophet as the first Mubayyin of the Qur'an, and the search for the hadiths was to explain the meaning of the verses according to the guidance of the Prophet, especially the traditions of morality towards the environment.

There are very basic differences in the research of the two variables. Moral terms are found explicitly, while environmental terms are not often found, so more readings are needed until the clues of the hadith are fully unveiled. For that reason, thematic analysis was also applied with reference to the method pioneered by Syuhudi Ismail [9].He opines that hadiths should be understood based on their characters because of the presence of the universal, local and temporary hadiths in the context. In fact, the appearance of some hadiths was preceded by certain reasons, yet some others were not. There are hadiths with general features, while there are some of them are associated specifically to context.

\section{RESULTS}

\section{A. Previous Studies}

An empirical evidence recommends that the theological environmental thoughts and doctrine followed by the movement of natural environment among Muslims should stress on the concept of "eco-sufism", which can be started from "eco-Islamic boarding schools" (eco-Pesantren) which may result in pious Muslims highly dedicated to their environment [10].The community of Pesantren can play central roles in promoting the realization of the eco-sufism concept in that the Islamic teachings in the context are polite and ec0-friendly Islam and friendly toward the creator. Thus, Islam will be the most important consideration here (there is some irony in this phrasing because Islam is traditionally associated with the colour. [11] Muslim ecology due to its inclusion of western and non-western environmentalism. Such an approach is necessary since Muslim environmental practices vary due to their unique sociological and cultural context [12].The aforementioned studies indicate that environmental education and natural environmental awareness are interrelated. 
A research entitled "Implementasi Pendidikan Agama Islam Berbasis Konservasi Lingkungan Hidup dalam Membentuk Karakter Siswa: Studi di Madrasah Tsanawiyah Sudirman Getasan Kabupaten SemarangTahun Pelajaran 2016/2017", which was authored by Yasin, unveiled that characters established through Islamic education based on the environmental conservation are categorized into two categories, namely individual character, such as being religious, discipline, creative, and independent; whereas, the second category was social character, which includes environmental care, social care and responsibility [13].The concept of Islamic education based environmental conservation has been presented in the secondary Islamic school's curriculum, which integrates education of natural environment with the Islamic education comprising of Alquran and Hadith, faith and attitude and Fiqh, which is developed by the teachers as evidenced in the lesson plans applied in the classrooms. For this reason, teacher competence about the importance of environmental conservation remains critical .

Yasin and Yeni Lestari stress on the importance of exemplary act from the teachers as the role models for implementing the environmental care. In addition, the family can also play in important role in empowering the character building. The schools should always attempt to help develop the parents' understanding about the environment through extended activities. This way allows both the parents and students to share similar understanding about the environment [14]. Yeni emphasizes the importance of communication between the family and school to yield the realization of early environmental care.

In some schools, in terms of cognition, the students have some adequate knowledge about the importance of environmental care. Similarly, in terms of psychomotor, the students are actively engaged in the environmental conservation that reflects the acts of environmental care at schools. However, in terms of affective, the students are not stimulated to encourage their friends to also partake in the environmental conservation.[15]. The study presents several principles for promoting students' awareness of the environment, namely habituation, availability of tools, enforcement of consistent rules of discipline, and exemplary.

Similarly, another study concluded that the issue of awarness does not lead to behavior in the environmental dimension [16].A guidance and model are needed to uphold the regulations and understanding as well as the synergy between the components in the social community. Similar conclusion is also demonstrated in an article that the activities should comprise habituation, exemplary, and learning by doing, such as outdoor learning activities. This allows learners to apply their attitude of environmental care in their daily lives [17]. The study concludes that habituation and exemplary are two critical components that determine the students' attitudes toward the environment.

Similar finding is also evidenced in the study by Mirza Desfandi [18]., which uncovered that promoting people with strong character can be effective through education in schools. A learning center, schools play special roles for plays; schools can help students understand the impact of 
people's deed on Earth. Adiwiyata Program can be applied to actualize the responsible school members in an effort to secure and conserve the natural environment through good school management for the sake of sustainable development.

Research at Harvard University in the United States shows that one's success is not much determined by knowledge and technical abilities (hard skills), but rather by the ability to manage themselves and others (soft skills). The study revealed that $20 \%$ of success is only determined by by hard skills, while soft skills are the determinant factors for the remaining $80 \%$ of success. In fact, the most successful people in the world are successful due to their soft skills rather than their hard skills, which is closely related to the quality of one's character [19].This demonstrates that character education grounded in the primary values becomes the key success of the future, including the character education based environmental care.

\section{B. Theory Analysis}

In the English-Indonesian dictionary written by John M. Echols and Hassan Shadily, it is stated that "karakter" (Indonesian word) derives from the English word "character", which literally means character or characteristics [20]. In the psychological dictionary as cited by M. Furqon Hidayatullah in his book "Guru Sejati: Membangun Insan Berkarakter Kuat dan Cerdas", it is stated that character is personality seen from the ethical and moral point of view, such as individual honesty, habitual characters. [21] Terminologically, character refers to the human characteristics in general, in which humans possess a myriad of characteristics heavily dependent on their own lives. Character is inner character, attitude, or noble deeds becoming special features of individuals or a group of people. from "The stamp of individually or group impressed by nature, education or habit", character is defined as the values of human behaviors that strongly relate to the Almighty god, the humans themselves, other people, environment and nation state, which are manifested in the thoughts, attitudes and deeds based on the religious norms, laws, customs, and culture [22].Character can also be defined as having similarity with attitudes and noble deeds, so the state characters are identical to the state attitudes and noble deeds.A nation with character is a nation that has character and virtue, whereas a nation that has no character is a nation that is not or lacks character or does not have a standard of good behavior [21].

Environmental care oriented character education is the focus of attention because character education is strongly related to all aspects of life.However, environmental awareness based character education is something that is very urgent due to the occurrence of several environmental crises that have a global impact that is mainly cause by the rapid ecounfriendly development. Education is deemed as the best strategy to cultivate 
character in the future generations from the early stage. Environment as a system (to understand so as to improve decision-making) calls for the development of systemic thinking: by analysing the components and relationships of the environment as an "eco-socio-system" (according to the expression proposed by Louis Goffin, 1999), one can gain a global understanding of environmental realities and thus have the necessary inputs for judicious decision-making. It is here that ecological education basically comes into play: it involves learning about the diversity, richness and complexity of one's environment; learning to define one's human "niche" in the global ecosystem; and learning to fill it properly [23].

In line with this, Fiqh experts, Prof. K.H. Ali Yafie, when discussing environmental fiqh, said that humans are expected to no longer take actions that cause a decrease in the quality of the environment, and that with full awareness, they should stop doing these actions, then turn back to activities that can preserve the environment so that the ecosystem can be conserved. There are many ways that can be done to provide a good understanding of the environment to each individual, such as through information, counseling, guidance, and education (formal and non-formal from kindergarten, elementary to tertiary) [24].

The environmental care is the manifestation of individual's mental trait that is reflected in their everyday life [25]. Tadkiroatun Musfiroh in [26] states that mental traits and attitudes can be classified into character. Character can be defined as characteristic, attitude, and personality of individual stemming from the result of internalization of various policies (virtues), which are used as the basis for thinking, behaving and acting. [26].The character of environmental care is not only a talent or inherited but also a result of education in general [25]. Misguiding or wrong education will result in a character of less commendable toward the environment. Therefore, a good character ought to be formed upon each individual so that they can internalize each of their deeds and attitudes. Early childhood experience has significant impacts on one's growth. If students are introduced how to take care of the environment at an early age, they will have positive characters in their future, a character of environmental care Giving environmental education at an early age will be capital for the future of the environment.

\section{DISCUSSION}

When dealing with the relation between humans and environment, Qur'an employs "nahyi" (prohibition) discourses. Several qur'anic verses و لا تفسدوا فى ... لdo not wreak any destruction on the Planet Earth...” (Qs. al-A 'raf/7

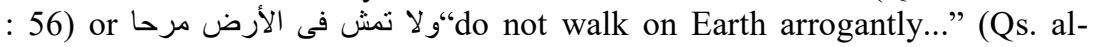
Isra/17: 37). The guidance of this holly book provides a framework of humans' relation with the nature, which is initially determent by the destructive acts. The principle for the pursuit of prosperity in Islam begins with protection or prevention against the negative impacts.

In terms of the discourse of prohibition (nahyi) in the Qur'an, the Prophet enumerates it specifically, which all lead to the protection of the 
most destructive consequences (mafsadat). In an hadith, the Prophet عuhammad SAW as narrated by 'Abdullah bin Hubsyi, who states: بن عبد الله

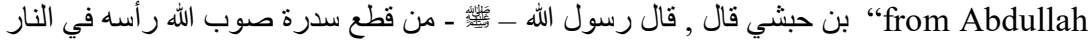
bin Hubsyi, the prophet said"anyone cutting off the Lote tree will be sent to hell by Allah"(Abu Dawud ,n.d.: 947, no. 5239)This hadith is a warning and threat for those intending to harm the nature, whose risks will be taken by the destroyers in the hereafter.

Sometimes the prophet encourages his adherents by presenting the long term benefits of conserving the nature. For example, the Prophet Pbuh equalize people planting trees as those who donate tithe as stated in the

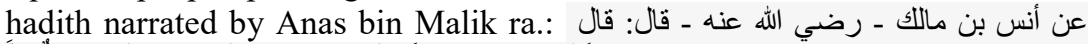

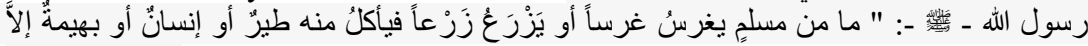
(from Anas, the prophet states that all Muslims cultivating trees or seeds taken or consumed by others, birds, or other animals, will be their tithe for themselves"[27]. This hadith encourages the importance of planting staple seeds to conserve. Drawing on the hadith above, planting trees deals with both earthy deeds and that of hereafter or spirituality through environmental conservation. Tree plantation not only deals with the economy but also eschatology (rewardukhrawi) as a means for reaping the spiritual merits for the long term (shadaqah jariah). This shows the striking difference from the theories of ecology that solely synergize triple aspects, namely social, economy, and ecology. The Western theories as aforementioned do not comprise the role of spirituality in the conservation of natural environment. Islam, on the other hand, pays much heed on the transcendental values that base the environmental conservation.

The movement of development toward developing the economic sector should ideally be directed to prioritizing the negative consequences. In the study of development and ecology, several theories of analysis on the impact of environment are presented. This is termed "Analisis Mengenai Dampak Lingkungan (AMDAL)" in Indonesian, which literally means the analysis of the impact of environment. AMDAL is a generic law that corresponds to the Islamic principles, which is protective (mafsadat) against the development and civilization to maintain the ecological balance. A study from the Ministry of Maritime and husbandry shows that the 2016 flood in Jakarta, the capital city of Indonesia, occurred due to environmental littering, rubbish [28].To anticipate and minimize the disaster, the government had actually stipulated the regulations pertinent to AMDAL prior to the presence of companies in the area. AMDAL was first introduced based on the constitution Article 16 No.4 Year 1982 about the conditions and principles of the natural environment conservation. Throuhout its course, the presidential regulation regarding AMDAL has faced several changes and suitability according to the needs( [29]

In the beginning, based on the law No. 23Year1997 about the natural environmental conservation, AMDAL was managed under a special commission in the central government, yet the regulation was changed by the

IJoASER,Volume 2,Issue 3, November,2019

DOI: 10.33648/ijoaser.v2i2.35

Copyriht: STAI AI-Furqan Makassar,Indonesia

Content License: CC-BY-SA 
Presidential regulation PP No.27/1999 due to various accounts. The big changes found in the presidential regulation are the omission of all commissions of AMDAL changed by a national commission of assessment under the auspices of BAPEDAL (the Environmental Impact Management Agency) in the regional level, namely the province that has regional assessment commission. If the assessment shows incompatibility to the environment, the respective institution may reject the proposal proposed.One important point stressed in the presidential regulation PP No.27/1999 is the accessibility of information and role of the people. The regulation of AMDAL has a significant role in the sustainability of humans' lives and all the natural ecosystems.

M. Quraish Shihab states that this verse contains the basic information. First, changes come from humans themselves, from within themselves as implied by the word 'anfusihim' (themselves). Second, the meaningful changes should be through a group of people as evidenced by the plural form in the verse. The changes should start with the overhaul of paradigm, perception, character building touching the inner part of humans By Yusuf. The changes in the system and regulations are not adequate to develop the character of environmental care because it is solely dependent on the humans themselves as the actor (the man behind the gun). In the Q.S. al$\mathrm{Ra}$ 'd/13: 11 above, the term 'anfusihim' "they themselves" shows "the internal part of the humans' in terms of ideas, mindset, and values found in their mind, and whose truth and benefits are believed to yield a strong will to make the changes come true. In realizing the changes, Qur'an goes through the basic principles in the verse. Islamic education derives from the noble values, namely spirituality connected in each movement of the environmental conservation.

To do some changes, the knowledge regarding the strategy is needed to deal with the environmental problems [30]. One of the principles is gradual (tadrij) and sustainable (istimrar).( NAAEE,2010).First, it should start from each individual [31]. The verse indicates that the education of values and character training can be a starting point to begin changes and expected behaviors. Second, families as the smallest unit in the society can play a significant role in the development of mental and awareness of the environment from the family members as stated in the Qur'an QS. alTahrim/66: 6. Third, the formal education institutions, from nursing education levels, primary to tertiary level. The development based eco-school awareness is needed, [31]. namely environmental awareness based school or university. This is then manifested in the Adiwiyata program based on the norms of togetherness, openness, equality, honesty, justice, and functional conservation of natural environment and natural resources.(Landriany, 2014: 82-88). This endeavor will be effective if it is started early as a direction of the verse.... أ..... waqul Rabbirham huma kama rabbayani Shagira... and just pray to your God, mercy both of them as how I was educated during my childhood... (Qs. al-Isra/17: 24).

Beginning to instill habits into embedded characters growing in the "inner side" or soul, namely touching students and cultivating their environmental awareness through education by integrating environmental 
awareness in the curriculum and all subject matters along with practice and example. However, the inadequacy of understanding of educators about the environmental education remains the critical issue. This is justified by the statement of Coyle who states that "people hold many misconceptions about the environment" [32]. In formal education, the natural environmental education is not too essential [33]Fourth, government should stipulate regulation so that it does not only comprise moral messages but also binding rules and consistently and fairly fined for those disobedient and appreciate who conserve the environment. Environmental education develops an environmentally literate citizency that makes choices that are better for the health of the environment, leading to a more sustainable planet. [35] In return, this will be a collective trait of the Indonesians as in the plural form 'anfusihim'. This is the true principle of Islamic education that embraces the principle of tadrij (stages), starting from the individual, family, school, regional law, government regulation and state law.

For sake of actualizing the tasks and roles of human leadership collectively, they should be controlled based on the binding regulations. This is the task and purpose of the state to realize the role of mankind as the caliph on the Planet Earth. AMDAL is a must if the government is serious in conserving the environment and preventing the negative consequences of the modern development. The learning of fiqh, noble deed, and ethics at schools focusing on the conservation of the environment is compulsory. The teaching of social interaction ethics (mu'amalah) developed towards the ethics of ecological interaction (mu'alamah) as the manifestation of the value rahmatan lil 'alamin.It also applies to the Sunnah (ways of living) of the Prophet Muhammad that these should not be taught in the context of spirituality and social interaction but also in relation to the relation of mankind with the environment. Planting trees, growing and protecting animals are ways of living of the Prophet Pbuh. In the learning of faith and oneness of god, conserving the beauty of nature is the manifestation of faith. The interconnectedness with the nature is not only a matter of life on Earth but also related to hereafter life. In the learning of Tasyawuf (Sufism), the nature is seed as tajalli(self-manifestation of god) or the manifested verses. Environmental education in Islam is closely related to faith and the concept of Tauhid (oneness of god), while Tauhid is the basic principle of Islamic teachings.

\section{CONCLUSION}

Edu-ecology is the very basic teaching of Islam. The presence of view that places humans the most noble creature on Earth making themselves as the subject exploiting the nature as their object has wrecked catastrophic damages on the natural ecosystem. The learning through educational environment and the law enforcement should be consistently and fairly carried out. Conserving the environment is the basic and vital teaching of

\footnotetext{
IJoASER,Volume 2,Issue 3, November,2019

DOI: 10.33648/ijoaser.v2i2.35

Copyriht: STAI Al-Furqan Makassar,Indonesia

Content License: CC-BY-SA
} 
Islam. The people's awareness developed through education that incorporates the spiritual values should aim to promote relationship between humans and their environment throughout the teaching and learning process. The character education oriented toward the environmental awareness requires some stages (tadrij), starting from the individual, (in)formal and non-formal education institutions, which should then be supported by the spiritual and transcendental values and regulation that support the effectiveness of the stages oriented to the environmental awareness. In addition, exemplary models are needed from the government, teachers, lecturers, parents, social and religious figures. The exemplary models are one of the powers and factors promoting the realization of the culture and character of environmental care.

\section{REFERENCES}

[1] Yusuf, Muhammad (2013). "Membentuk Karakter Melalui Pendidikan Berbasis Nilai”. Jurnal al-Ulum, Jurnal Studi Islam IAIN Gorontalo, Volume. 13 Nomor 1, Juni 2013. p. 5.

[2] UU No. 20 Tahun 2003 tentang Sistem Pendidikan Nasional Pasal 3.

[3] Robbi,Moh. Da'i. (2016). "Pendidikan Pelestarian Lingkungan Hidup dalam Islam: Keseimbangan Ekosistem Prespektif Hadis", Jurnal AlIbtida'. Vol. 4, No. 2, 2016. p. 62

[4] Fritjof, Capra (2000). Titik Balik Peradaban: Sains,Mayarakat, dan KebangkitanKebudayaan, Terj. M. Thoyibi, Yogyakarta: Bentang. p.562.

[5] Sonny Keraf (2002), EtikalJtigkmgan,]dkziXA: Kompas, p. xiii.

[6] Mudzhar, Atho (2010). Membumikan Fikih Ramah Lingkungan' dalam Mudhofir Abdullah, Al-Qur'an dan Konservasi Lingkungan'. Jakarta, Dian Rakyat, p. xxx-xxxvi.

[7] Baqy, Fu'ad 'Abd al- (2012). al-Mu'jum al-Mufahras li Alfaz al-Qur'an al-Karim. Beirut-Libanon: Dar al-Ma'rifat.

[8] Salim,Abd Muin(1999). "Metodologi Tafsir Sebuah Rekonstruksi Epistemologis Memantapkan Keberadaan Ilmu Tafsir sebagai Disiplin Ilmu".Naskah Pidato Pengukuhan Guru Besar. IAIN Alauddin Ujung Pandang. P. 7.

[9] Ismail,M. Syuhudi (1994). Hadis Nabi yang Tekstual dan Kontekstual: Telaah Ma'ani al-Hdis tentang Ajaran Islam yang Universal, temporal dan Lokal.Jakarta; PT Bulan Bintang. p. 5

[10] Imamah,Fardan Mahmudatul (2008). Menghadapi Kapitalisme Pendekatan ECo-Sufism Dalam GerakanEnvironmentalisme Islam Indonesia. New York: Continuun.

[11] Reuter, Thomas (2015). "The Green Revolution in the World's Religions: Indonesian Examples in International Comparison." Religions 6. (4): 2015, 1217-31. https://doi.org/10.3390/rel6041217.

[12] Saniotis, Arthur Saniotis (2012). "Muslims and Ecology: Fostering Islamic Environmental Ethics." Contemporary Islam 6 (2). 2012, 15571. https://doi.org/10.1007/s11562-011-0173-8. 
[13] Yasin (2016). "Implementasi Pendidikan Agama Islam Berbasis Konservasi Lingkungan Hidup dalam Membentuk Karakter Siswa: Studi di Madrasah Tsanawiyah Sudirman Getasan Kabupaten Semarang Tahun Pelajaran 2016/2017"Tesis, Program Pascasarjana IAIN Salatiga, 2017. p. 40.

[14] Anwari, Amirul Mukminin al- (2014). "Strategi Pembentukan Karakter Peduli Lingkungan di Sekolah Adiwiyata Mandiri”. Jurnal Ta'dib. Vol. XIX, No. 02, p. 229.

[15] Ratnawati, Tina (2018). "Pengendalian Sistem Ekologi, Sosial, dan Ekonomi untuk Meningkatkan Kualitas Gaya Hidup (Lifestyle) Masyarakat di Perkotaan, Peran MST dalam Mendukung Urban Lifestyle yang Berkualitas", Jurnal Perencanaan Wilayah dan Kota. BSAPPK. P. 193.

[16] Volk, Harold R. Hungerford and Trudi L (2018). Changing Learner Behavior through Environmental Educatian. p. 267.

[17] Carly R Ackley, Clarly(2009). "Leadership in Green Schools: School Principals as Agents of Social Responsibility". Dissertasi. The Pennsylvania State University. Pennsylvania: unpulished.

[18] Desfandi,Mirza. (2015). "Mewujudkan Masyarakat Berkarakter Peduli Lingkungan Melalui Program Adiwiyata". Jurnal Sosio Didaktika. Social Science Education Journal, 2(1). P. 31-37. doi:10.15408/ sd.v2i1.1661.

[19] Yusuf, Muhammad (2013). Horizon Kajian Al-Qur'an, Pendekatan dan Metode.Makassar: Alauddin University Press, 2013, hal. 42.

[20] Echols, John M. dan Hasan Shaadily (1997). Kamus Inggris-Indonesia. Jakarta: PT Gramedia Utama. P. 107

[21] Hidayatullah,M. Furqon (2010). Guru Sejati: Membangun Insan Berkarakter Kuat daan Cerdas. Surakarta. Yuma Pustaka. p. 9.

[22] Tobroni (2010). Pendidikan Karakter dalam Perspektif Islam. http://tobroni.staff.umm.ac.id.2010/11/24.pendidikan-karakter-dalamperspektifislam.pendahuluan. 12 March 2012.

[23] Sauvé, Lucie. (2002).Environmental Education: Possibilities and Constraint. Universitié du Québec à Montréal, Connect v. xxv11, 2002. n. 1/2. p. 2.

[24] Yafie, Abu Dawud. Sunan Abi Dawud. p. 947, hadith number 5239

[25] Hamzah, Syukri (2013).Pendidikan Lingkungan: Sekelumit Wawasan Pengantar. Bandung: Refika Aditama. p. 43.

[26] Sulistyowati, Endah (2012). Implementasi Kurikulum Pendidikan Karakter. Yogyakarta: Citra Aji Parama. p. 20

[27] Al-Tirmizi (n.d.). Sunan al-Tirmizi, 327, hadith number 1382;

[28] Buchori, Abdusshomad (2009). Respon Atas Berbagai Masalah Kemasyarakatan dan Keumatan. Surabaya :Majelis Ulama Jawa Timur. p. 169.

IJoASER,Volume 2,Issue 3, November,2019

DOI: 10.33648/ijoaser.v2i2.35

Copyriht: STAI Al-Furqan Makassar,Indonesia

Content License: CC-BY-SA 
[29] Landriany,Ellen (2014). “Implementasi Kebijakan Adiwiyata Dalam Upaya Mewujudkan Pendidikan Lingkungan Hidup di SMA Kota Malang”. Jurnal Kebijakan dan Pengembangan Pendidikan. Volume 2, Nomor 1, Januari 2014. p. 82-88.

[30] Mayer, F. Mogensen \& M. (Eds.) (2005). Eco-School trends and divergences: A comparative study of Eco School development process in 13 countries. Vienna: Austrian Federal Ministry of Education, Science and Culture. Dept. Environmental Education Affairs

[31] Mas'ud, Muhammad Khalid (1996).Fislafat Hukum Islam, Studi tentang kehidupan dan pemikiran Abu Ishaq Al-Syatibi.Bandung : Penerbit Pustaka. p. 200.

[31] Coyle, K. (2005).Environmental Literacy in America: What Ten Years of NEETF/Roper Research and Related Studies Say about Environmental Literacy in the U.S. Washington, DC: National Environmental Education and Training Foundation. Retrieved from http://eric.ed.gov/PDFS/ED522820.pdf

[33] Sungkowo (2005). Konsep Pendidikan Lingkungan Hidup Pada Jalur Pendidikan Dasar dan Menengah. Jakarta: Dikdasmen

[34] Lipson, Charles (2011). Cite right: A quick guide to citation styles; MLA, APA, Chicago, the sciences, professions, and more (2nd ed.). Chicago [u.a.]: University of Chicago Press. p. 187. ISBN 9780226484648. 